\title{
Det litterära reportaget hos Ryszard Kapuściński som ett gränsöverskridande historiografiskt och biografiskt projekt
}

\section{Av Timo Menke}

\section{Inledning och bakgrund}

Böckerna På resa med Herodotos ${ }^{1}$ och Reporterns självporträtt ${ }^{2}$ är det närmaste man kommer ett biografiskt arbete eller ett journalistiskt testamente av Kapuściński över sitt yrkesliv som resande reporter. Här reflekterar han över sitt gränsöverskrivande arbete någonstans mellan litteratur och journalistik. Relativt kort efter hans död 2007 utkom en mycket kritisk biografi av före detta kollegan och lärjungen Artur Domoslavski, med titeln Kapuscinski Non-Fiction (2010), ${ }^{3}$ som utsatte Kapuścińskis livsverk för en hård postum granskning. Kapuścińskis grundmurade rykte som trovärdig författare och journalist solkades, hans textproduktion tycktes vara mera roman än reportage.

Mig veterligen finns det inga andra heltäckande biografier över Kapuściński, däremot otaliga artiklar, recensioner och omnämnanden som är övervägande positiva och hyllande; se till exempel den tunna hyllningsskriften På resa med Kapuściński av hans svenske översättare, som utkom efter hans död (Bodegård \& Söderberg 2007) . Utan att kunna arbeta med innehållet i Kapuściński Non-fiction (som än så länge endast är utgiven på polska, som också var Kapuścińskis arbetsspråk) menar jag ändå att boken har generat en ny vaksamhet för både det litterära och det verklighetstrogna i Kapuścińskis reportage, som kan användas för en kritisk läsning i ett biografiskt ljus.

Varken På resa med Herodotos eller Reporterns självporträtt kan dock betraktas som explicit biografiska. Jag har valt att bortse från andra titlar i hans textproduktion som sysslar med porträtt till förmån för en fördjupad bild av de biografiska metoderna i den utvalda litteraturen. Jag kommer här främst att intressera mig för hur t ex Kapuściński läser Herodotos, och hur han använder honom för sina syften. Tonvikten ligger på På resa med Herodotos, medan Reporterns självporträtt behandlas ganska komprimerat, delvis på grund av att den senare endast är en auktoriserad textsamling - ett slags best-of-sentenser - och som sådan endast nödtorftigt redigerad till en bok.

1 Kapuściński, Ryszard (2006). På resa med Herodotos. Stockholm: Bonnier (översättning: Anders Bodegård).

2 Kapuściński, Ryszard \& Straczek, Krystyna (Red./utgivare) (2009). Reporterns självporträtt. Stockholm: Bonnier (översättning: Anders Bodegård).

3 Domosławski, Artur (2010). Kapuściński non-fiction. Warszawa: Świat Ksiazki.

4 Bodegård, Anders \& Söderberg, Maria (2007). På resa med Ryszard Kapuściński. Enskede: Maria Söderberg. 
Ryszard Kapuściński (1932-2007). Foto av Mariusz Kubik från den 17 maj 1997. Bildkälla: Wikimedia Commons (CC BY-SA 3.0).

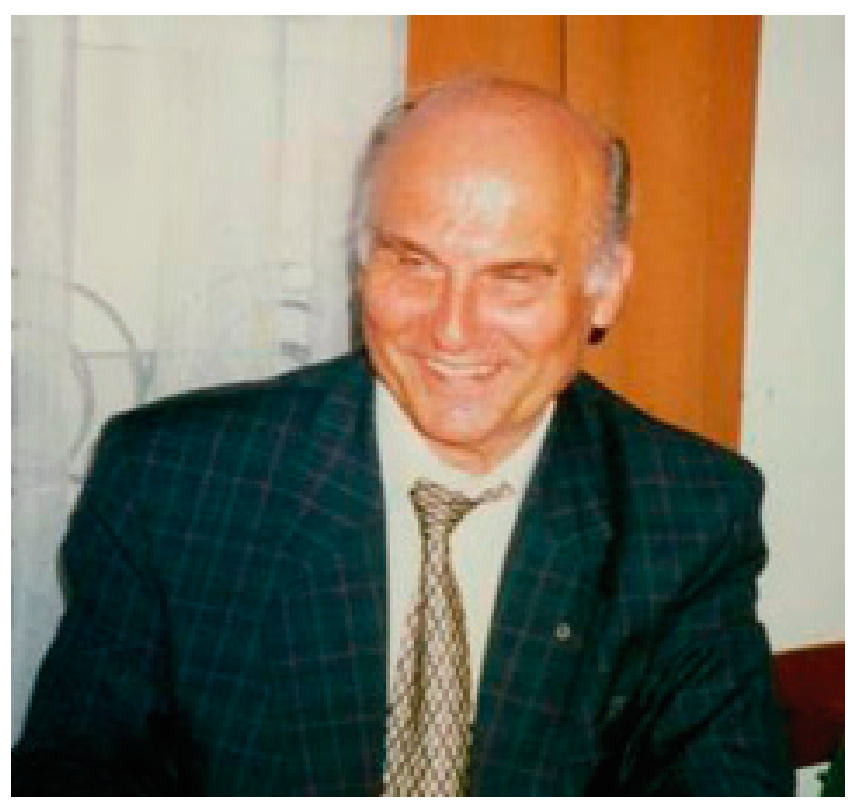

\section{Syfte}

Det finns drag i Kapuścińskis textproduktion som kan beskrivas som gränsöverskridande i vid bemärkelse: vandringar i geografiska gränstrakter, upplösta genregränser och relativt hybridiserade metoder är alla kännetecken för en typisk text av Kapuściński. Vill man etikettera texterna ifråga om genre används ofta begrepp som essä, porträtt och reseskildring (jfr Hochschild 1997) ${ }^{5}$. Kapuściński själv beskriver aldrig sitt arbete i termer av biografi, historiografi eller litteratur och gör heller inga anspråk på att vara företrädare för en särskild genre. Mitt syfte är att spåra och om möjligt frilägga biografiska och historiografiska metoder snarare än resultat, så som de kan urskiljas genom en kritisk läsning. Den starka betoningen av det autentiska nuet, liksom den språkliga gestaltningen, bär ofta spår av både berättande levnadsteckning och dokumentär historieskrivning. I de utvalda böckerna reflekterar Kapuściński över hur det gränsöverskridande arbetet någonstans mellan litterärt-konstnärliga och historiskt-journalistiska förhållningssätt har gått till i hans textproduktion. Han gör det inte i explicit självbiografisk eller memoarisk form, eller som en poetik, utan använder sig av Herodotos som samtalspartner och reskamrat, samt av spridda utdrag ur sin egen produktion. Reflektionerna själva antar kongenialt nog återigen formen av en hybrid mellan skönlitterära och reportageliknande textformer.

I brist på en bra beskrivning vågar jag kalla metoden för metabiografisk snarare än biografisk eller autobiografisk. Det finns motiv och teman i den utvalda litteraturen som kan ses som en biografisering av journalistiskt skrivet material med litterära förtecken, att text görs av text i syfte att få kunskap om människors liv - även det egna.

5 Hochschild, Adam (1997). Finding the trapdoor : essays, portraits, travels. Syracuse, N.Y.: Syracuse University Press. Ett kapitel med namnet "Magic Journalism” är helt ägnat åt Kapuściński. 


\section{Undersökningar om Kapuściński}

Intressant i sammanhanget är hur relativt anonym människan Kapuściński har kunnat förbli, sitt världsrykte till trots. Under sina 50 år som resande korrespondent och sedan 70-talet som frilansande journalist och författare har han sett och skrivet om i stort sett alla kontinenter och ett otal konflikter, kriser och krig. Boken På resa med Herodotos ${ }^{6}$ utkom på polska år 2004 och skildrar utvalda reseögonblick som reporter från 1956 och framåt i korta novelliknande stycken, vid sidan om kommenterade citat ur Historia. Under många år ${ }^{7}$ hade Kapuściński med sig Herodotos ${ }^{8}$ storverk Historia ${ }^{9}$ i en polsk översättning från 1955. Boken börjar med att Kapuściński skickas iväg på sin första resa till Indien med ett färskt exemplar av Historia i väskan. Med undantag för ett enstaka barndomsminne börjar Kapuścińskis litterära liv bokstavligt talat i det ögonblicket han skickas iväg på resan (jfr Popkins, 2005) ${ }^{10}$. Den intensivt omhuldade önskan att få ”överskrida en gräns”"11 utgör själva startpunkten på hans liv som reporter: resa, skriva och leva skildras som ett uppdrag med tydlig början men öppet slut.

\section{På resa med Herodotos}

Vid tiden för utgivningen av boken 2004 är Kapuściński känd och högaktad för en genre som ofta benämns som litterärt reportage eller essäistisk journalistik. I hans produktion används fakta skickligt som betydelsebärande och berättande element snarare än enbart fakta. Det gäller valet av händelser, t ex tidpunkten för utgivningen av Historia (strax efter Stalins död), platserna långt utanför dåvarande östblocket, eller urvalet av de citerade och kommenterade styckena ur Historia. Även om Herodotos också var en flitig resenär för sin tid, är det ingalunda så att Kapuściński med boken i handen reser i Herodotos fotspår. Deras vägar korsas på en rad platser, men närläsningen sker med andra förtecken. Herodotos' uppdrag liknas vid Kapuścińskis: resa och skriva. På resa med Herodotos kan läsas som en hybridbok av Kapuściński utan entydig genremässig hemvist, "även bland recensenter finns olika uppfattningar om att Kapuścińskis bok är en essä, en reseskildring och en doku-

6 Kapuściński, Ryszard (2004). Podróze z Herodotem. Kraków: Znak.

7 Exakta orts- och tidsangivelser och korrekta årtal är en återkommande bristvara för att vara reportage, det gäller särskilt rapporteringen av de självupplevda händelserna. Utgivningsdatum för böcker eller årtal för historiska händelser är Kapuściński relativt noga med. I På resa med Herodotos förekommer ofta ett slags relativistisk tidräkning: "(...) Ett århundrade tidigare har skyterna intagit medernas land (...) och sedan härskat över dem i tjugoåtta år" (Kapuściński, R., 2004, s. 144).

8 Herodotos, ca 485-ca 425 f.Kr., grekisk historiker från Halikarnassos. Herodotos tillbringade mycket tid på resor, till Egypten, Mesopotamien, Syditalien och Svarta havet, och var länge bosatt i Athen. Hans verk om krigen mellan greker och perser 499-478 är avfattat på östjonisk dialekt. Dispositionen är delvis svåröverskådlig, då berättelsen ofta avbryts av långa utvikningar med historiskt, geografiskt och etnografiskt innehåll (Källa: www.ne.se/herodotos).

9 Herodotos, ca 485-ca 425 f.Kr. (Författare). Herodotos från Halicarnassus Muser, eller Nio historiska böcker (översättning: Carlstedt, Fredrik, 1797-1844). Stockholm, 1832-1833. Verket har sedan sin tillkomsttid givits ut i ett otal upplagor och översättningar, den första på svenska år 1832; den senaste pocketupplagan är från 2008. Titeln Historia betyder egentligen "undersökningar" (av grek. $\square \sigma \tau$ бopía historía) och upptas först i det latinska språket, för att så småningom få sin moderna betydelse.

10 Popkin, Jeremy D. (2005). History, historians, \& autobiography. Chicago: University of Chicago Press. Om man bortser från frågan om den judiska identiteten, arbetar Kapuściński snarare som sitt reportages överlevande och vittne till händelserna än som berättare med utökat livspanorama.

11 Kapuściński, 2006, s. 16. 
mentärroman" (Kotowska Hagström, Światosława (2007). ${ }^{12}$ Varje försök att mera exakt ringa in boken i termer av reseskildring, reportage, porträtt, eller rentav livsresa visar sig vara svårt. Det beror troligen i huvudsak på att Kapuściński här avviker från sin vanliga textproduktion. Denna gång reser han på två ovanliga kontinenter: Herodotos’ Historia och de egna reseminnena, varför begreppet tidsresor eller mentala resor ligger nära till hands. ${ }^{13}$ Båda resornas motor är text, eller snarare de bilder texten frambesvärjer, Kapuściński använder själv begreppet "ikonografisk resa" när han refererar till studiet av annan reselitteratur (Kapuściński 2006). Men inte ens en sådan definition lyckas ringa in projektet till fullo.

Större delen av boken ägnas åt intensiva färder i Herodotos’ Historia. Det är en i allra högsta grad subjektiv läsning med långa och många citat och utvikningar för de komplexa intrigerna, konflikterna och krigen. Tätheten i de citerade styckena är ibland påfrestande komplicerad för en oinvigd Herodotos-läsare. Korrespondenten Kapuściński möter här (den förste) historikern och reportern Herodotos. Blandningen av citat och kommentar, grafiskt åtskilda endast genom kursivering utan kapitel- eller sidangivelser, sker i nyckfulla språng och med en lätthet som kan verka förvirrande, eller i varje fall få gränserna mellan Kapuściński och Herodotos som författare att bli transparenta och flytande.

De övriga partierna, åtskilda av kapitel, eller löst insprängda i den löpande läsningen av Herodotos, utgörs av minnesfragment ur Kapuścińskis många reseanteckningar. De presenteras löst upphängda enligt deras inbördes kronologi, men det kan bli om- och genvägar. Som läsare skickas man - liksom i analogi till författaren - till godtyckligt utvalda länder och kontinenter, från Polen till Indien, vidare till Kina och runt i Afrika. Världen vidgas ständigt och den etniska, kulturella och språkliga mångfalden framstår som överväldigande. Om inte direkt självbiografiska utgör dessa kortare prosastycken ändå minnesanteckningar om hållpunkter, återvändsgränder och mellanlandningar.

\section{Mål och motiv hos Kapuściński}

Man kan fråga sig vad målet är för Kapuściński som reporter, som korrespondent, som porträttör, som historisk antropolog, som västerlänning från östblocket. Vart vill han komma med sina reseskildringar, vad är hans motiv, vad vill han berätta? Kapuściński skriver utan notapparat, han anger i princip aldrig sina källor. Hans mest kända skildringar i bokform är varken dagsaktuella eller på annat sätt faktagranskade av en redaktion. Kapuściński talar oftast i egen person, men gör sig som författare ganska transparent för läsaren, texterna blir ofta till språkrör för någon annan: Haile Selassie, Muhammad Riza Pahlavi, eller andra icke-namngivna människor. Oavsett om det rört sig om tur, noggranna förberedelser eller journalistisk instinkt har han haft förmånen att ha varit på rätt plats vid rätt tillfälle, just när ett krig bryter ut, en kejsare störtas eller ett rike imploderar. Närvaron mitt i händelsernas centrum har genererat en trovärdighet för honom som auktoritet, de inkännande och sam-

12 Kotowska Hagström, Światosława (2007). Bilden av boken På resa med Herodotos av Ryszard Kapuściński i den polska och svenska dagspressen. Magisterkurs i polska VT2007. Stockholm: Stockholms Universitet, slaviska institutionen.

13 ”Jag berättade för honom [Jarda] hur jag hade fått den som reselektyr och hur jag under läsningen inlett två parallella resor - den ena bestod i att utföra mina reporteruppgifter, den andra gjorde jag $\mathrm{i} \mathrm{He}-$ rodotos fotspår" (Kapuściński 2006, s. 267). 
tidigt nyktra porträtten har vittnat om direktkontakt och därmed autenticitet. Författarens egna upplevelser utgör ofta basen för det som ger näring åt inlevelsen i skildringen. Längre fram återkommer jag till hur Kapuściński kan sägas verka innanför diskursen för den s.k. kognitiva auktoritet som lanserades av Patrick Wilson.

Det finns ofta en fruktbar differens mellan att å ena sidan vara närvarande som subjekt (det mesta är skrivet i jagform), men förhållandevis frånvarande som person (få personliga eller biografiska detaljer används i karaktärsteckningen). Berättaren Kapuściński uppstår ofta för läsaren först i läsandets ögonblick, i berättelsens absoluta nu. Melberg har beskrivit stilen som "en mångfald presentistiska ögonblick" där "Kapuściński förvandlar sig till en kör av vittnesmål och en sky av vittnen" (Melberg 2005) ${ }^{14}$, vilket även är en högst relevant beskrivning av På resa med Herodotos, med hänsyn till de många lagren av överlappande berättelser i skilda historiska tider.

Bortom yrkets självklara ambition att beskriva och förklara världen åt läsaren kan ett annat huvudmotiv urskiljas: Genom att resa och skriva, att beskriva resorna, att beskriva platserna, händelserna, människorna, liksom resandets vedermödor, kan han fokusera på ett annat motiv. Kapuściński återkommer till det som ett mantra i både kapitelrubriker och löptext: "att överskrida en gräns”. Jag skulle vilja tillägga: att nå utöver eller bortom sig självt, att nå fram till det/den främmande bortom gränsen, inte minst bortom gränsen för den egna personen och identiteten. Dessa resebeskrivningar rymmer biografiska aspekter, Kapuściński skriver om sitt liv på resande fot och skildrar därmed även sin egen livsresa. Som ovan föreslaget sker det som en biografisering av de egna upplevelserna och erfarenheterna med litterära förtecken, i syfte att få kunskap om andra människors liv - och därmed också sitt eget.

\section{Kapuścińskis undersökningar av Herodotos}

\section{Herodotos arbetsmetod}

Kapuściński återkommer till sin fascination inför Herodotos, "Gång på gång gjorde jag försöket att komma in i denna värld, göra mig hemmastadd där, göra den till min.” (Kapuściński 2006). Han är förtrogen med Historia med en aldrig sinande nyfikenhet kring både innehåll och form. Varför Herodotos reser och skriver, vad han skriver om och hur han samlat ihop fakta och skrivit sina undersökningar, upptar Kapuściński genom hela boken. Redan i början tycks han få kontakt med honom genom lagren av tid, man får intrycket att Kapuściński även skriver om sig själv:

På min jakt efter böcker om Indien passade jag på att fråga om det fanns något om Herodotos. Herodotos hade nämligen väckt mitt intresse, jag började känna sympati för honom. Jag var tacksam för att han varit mig till stöd med sin bok i mina vilsna och osäkra stunder i Indien. Att döma av hans sätt att skriva var han öppet inställd till sina

14 Melberg, Arne (2006). Resa och skriva: en guide till den moderna reselitteraturen. Göteborg: Daidalos. 
medmänniskor och nyfiken på omvärlden, han hade fullt av frågor att ställa och var redo att färdas hundratals kilometer för att få svar på några av dem (Kapuściński 2006).

Kapuściński upprättar en lista över frågor han vill ha svar på, till synes sporrad av hur lite som är känd om personen Herodotos. Han ger därvidlag också ett smakprov på sitt biografiska intresse och sin litterära ambition, men även på en metod:

Vad är lille Herodotos för ett barn?

Ler han mot alla och envar och räcker beredvilligt fram sin lilla hand, eller tjurar han och gömmer sig i mammas kjolar? Är han en evig lipsill och surpuppa, så att den plågade mamman sucka och säger: 'Å, gudar, varför har jag fött detta barn!' Eller är han ljus till sinnet och sprider glädje överallt? Är han lydig och artig eller tröttnar han alla med ständiga frågor: 'Var kommer solen ifrån? Och varför sitter den så högt så jag inte når upp till den? Och varför gömmer den sig i havet? Är den inte rädd att den ska drunkna? (Kapuściński 2006).

Här märks Kapuścińskis intresse för en psykologisk profil att bena ut drivkrafter och motivationer med. Men han visar inget vetenskapligt historiskt intresse för sin litterära reskamrat. Han diskuterar inte källornas inbördes trovärdighet annat än i förbigående. Det går inte att avgöra vilka "undersökningar" han överhuvudtaget själv har företagit för att genomlysa Herodotos. Kapuścińskis metod är i stället att uppfinna en fiktiv biografi över Herodotos med en katalog av detaljerade och aningen retoriska intervjufrågor. På så sätt kan han indirekt åt läsaren fabulera fram en barndom, spekulera kring uppväxt och yrke åt Herodotos, allt formulerat som alternativa vägval och riktningar. Kapuściński utvecklar ett möjligt tolkningsraster, ett sätt att förstå eller åtminstone närma sig Herodotos. Det är inte möjligt att avgöra om Herodotos här får låna drag av barnet Kapuściński, men Kapuściński använder sig av en biografiskt förvaltad erfarenhet av att se världen med barnets ögon. Han läser Herodotos uppmärksamt, valfrändskapen går nästan att ta på:

Herodotos inleder sin bok med en passage där han redovisar sina motiv för att skriva den:

Detta är Herodotos från Halikarnassos undersökningar, vilka han ger offentlighet, på det att allt det som hänt människorna inte skall utplånas ur minnet, och de stora och beundransvärda verk som utförts av såväl hellener som barbarer inte skall förklinga utan eko, varvid han särskilt utreder orsakerna till deras fejder...

Den inledande passagen är nyckeln till hela boken.

För det första meddelar han här att han gjort "undersökningar". Vi vet numera att han ägnade hela sitt - för den tiden långa - liv åt detta. Varför gjorde han det? Varför fattade han detta beslut i sin ungdom? Var det någon som uppmuntrade honom till det? Eller tog Herodotos tjänst hos en magnat? De äldstes råd? Ett orakel? Vem behövde hans arbete? Till vad? (Kapuściński 2006)

Samtidigt som Kapuściński försöker att reda ut Herodotos' motiv försöker han även klargöra sina egna motiv. Som läsare sitter man böjd över Kapuściński, som sitter böjd 
över Herodotos, som sitter böjd över sina undersökningar. En skrivarverkstad ryms i en annan och läsaren får delta i det för korta ögonblick transparenta skeendet med en blick över axeln - närmast ett metafiktivt grepp. Kapuściński formulerar en agenda så som han uppfattar den hos Herodotos, en agenda som också passar hans egna syften:

I Herodotos värld är människan (så gott som) den enda minnesdepån. För att komma åt det som är lagrat i minnet får man alltså söka upp henne, och om hon bor långt borta får man ta sig dit, ge sig iväg, och när man har mött henne sätter man sig ner och lyssnar på vad hon har att säga. Lyssna, lägga på minnet, kanske skriva ner: det är så reportaget kommer till.

Herodotos reser alltså runt i världen, han möter människor och lyssnar på dem. De talar om vilka de är, berättar sin historia. Men hur vet de vilka de är, var de kommer ifrån? Det har de hört av andra, framför allt sina föräldrar, som fört vidare vad de visste, som de själva gör nu. Och vetskapen har formen av olika berättelser. Folk sitter runt lägerelden och berättar. Med tiden kommer det att kallas för legender och myter, men i det ögonblick då man talar och lyssnar, tror man att det är rena rama sanningen, verkligheten själv (Kapuściński 2006).

Kapuściński skriver in sig själv och sitt uppdrag i en tradition av lyssnande och skrivande som tycks börja med Herodotos' berättelse, men förhåller sig relativt okritisk till Herodotos' metod som (ännu) inte gör skillnad på vetenskap och konst, dikt och sanning. Han läser sin Herodotos som lyssnar på människan: källan till kunskap om sig själv och förmedlare av samma kunskap i form av muntlig berättare. Boken igenom finns här en beundran och respekt för Herodotos motiv som gränsar till det hagiografiska. Allting beskrivs i okomplicerade och nästan barnsligt enkla termer. Om man är lika beredd att lyssna på Kapuściński, "tror man att det är rena rama sanningen, verkligheten själv".

Prosans presens i kombination med det typiska anonymiserade indirekta talet som tyder på en implied author är betecknande för Kapuścińskis stil och markerar en tunn gräns mellan reportagets sakliga nu och historiens fiktiva då: "Men hur vet de vilka de är, var de kommer ifrån? Det har de hört av andra, framför allt sina föräldrar." (Kapuściński 2004). Detta bidrar enligt Arne Melberg till att Kapuściński måste räknas som en "modernistisk reseberättare med poetiska böjelser" där "progressionen [är] ersatt av en mångfald presentistiska ögonblick" (Melberg, 2005) Men även om de stilistiska medlen är noga utvalda, försöker de att göra sig transparenta, flyktiga och omärkliga, allt i syfte att gestalta inlevelsen, att förstå och tolka grekens uppdrag som närmast blir en metafor för resandet självt.

Han var fullt upptagen av att förbereda sina resor, genomföra dem, sedan sovra och sortera materialet han fått med sig hem. Resan börjar ju inte i det ögonblick man ger sig av och slutar inte när man kommit till målet. I själva verket börjar den långt tidigare och slutar i praktiken aldrig någonsin: bandet med minnena rullar vidare även om kroppen inte rör sig ur fläcken. Reseviruset är en vådlig smitta, och sjukdomen är obotlig. (Kapuściński 2006).

Resans mål för journalisten Kapuściński handlar i stor utsträckning om att vara där, en resa föder en annan resa. Identifikationen med Herodotos som en lärd forntida an- 
tik reporter är närmast total, den biografiska överföringen är den förenande länken: 'Ja, Herodotos bok har uppkommit ur resan, det är det första stora reportaget i världslitteraturen. Dess författare har reporterns intuition, reporterns öga och öra. (...) världen går att beskriva" (Kapuściński 2006).

Men resandet som motiv har även andra aspekter, "Kapuściński reser inte - som Arne Melberg påpekat - mot ett mål utan i ringar runt målet - Afrika, Imperiet - och sedan kors och tvärs däri” (Wästberg 2009). Något implicit autobiografiskt kan här uppfattas som en sidoprodukt: hur resorna rapporterar om personen Kapuścińskis cirkulära väg genom världen. De samlas i resedagböcker, fyllda med betraktelser och reflektioner kring reporterns belägenhet. Mötena och gränsöverskridanden sker i en värld full av faror, konflikter och krig. Att utöva sitt yrke på liv och död ger skildringen en enorm klangbotten, åtminstone är det så skildringen gestaltas. Kapuściński använder sig medvetet genom hela sitt författarskap av autentiserande grepp i syfte att gestalta reportagets närvaro.

\section{Berättaren Kapuściński}

I sin bok Författarens verktygslåda (Thurén 2006) (15 $^{15}$ Thurén upp Kapuściński som exempel på en journalistisk författare. Thurén jämför berättargreppen i Ebenholts, en samling reportage om Afrika från 60-talet och framåt, med omvänt motsvarande grepp i Imperiet. Thurén intresserar sig för Kapuścińskis olika skildringar av väntande som handlar om det annorlunda sinnestillstånd som kan infinna sig. Beskrivningen av väntande afrikaner på en buss i Ghana 1958 kan med dagens ögon tyckas fördomsfull, på gränsen till rasistisk: "Eftersom jag timme efter timme har observerat hela folkhopar i detta livlösa tillstånd av väntande vågar jag påstå att de råkat in i en djup, fysiologisk sömn: de äter inte, dricker inte, urinerar inte. (...) Vad händer under tiden i huvudet på dem? Jag vet inte, har ingen aning” (Thurén 2006). Utdraget kontrasteras mot ett stycke ur Imperiet på resa genom Sovjetunionen 1989. Kapuściński och hans medpassagerare sitter fast i Jakutsk i väntan på ett flyg. I den självupplevda beskrivningen har väntandets passivitet blivit universell, så "som miljoner och åter miljoner människor på jorden tillbringar all sin tid" (Thurén 2006). Tolkningen av främmande människors yttre beteende har ersatts av en egen erfarenhet och tycks med ens begripligt och vardagligt. Den för den senare Kapuściński så viktiga inlevelsen i andra människor som berättargrepp har här förfinats. Mycket förblir implicit, Thurén kallar det förklaring genom konkretion, ett gestaltande grepp som ställer krav på läsarens uppmärksamhet. Författarens egna upplevelser kan alltså enligt Thurén bilda en särskild kunskapskälla, som i Kapuścińskis fall ger näring åt inlevelsen.

Thurén beskriver hur jämförelser mellan läsarens förutfattade meningar och verkligheten liksom nationella, etniska, tidsmässiga, ideologiska, könsmässiga och klassjämförelser hör till ett av författarens viktigaste verktyg. Jämförelser kan utvinnas för att betona skillnader eller likheter och på så vis skapa kontrast eller enhetlighet i berättelsen. Kapuścińskis olika upplevelser av väntan visar hur det egna livets erfarenheter och livstiden själv bidrar till en tydlig skillnad i det berättade; författarens position skapar avtryck i berättelsen. Kapuściński använder sig av en underförstådd jämförelse där han "tolkar och förklarar 15 Thurén, Torsten (2006). Författarens verktygslåda: att läsa och skriva sakprosa. Stockholm: Liber. 
främmande kulturer (...). Han hänvisar enbart till sina personliga erfarenheter. Hans två versioner av människors väntan visar betydelsen av sådan erfarenhet, men också hur osäker den är" (Thurén, 2006). Kapuściński som en journalistisk författare med ett ben i det litterära föredrar att visa och att tala om, men utbrister knappast i argumenteringar, än mindre i kritiska diskussioner med sig själv.

Talrika och detaljrika episoder i På resa med Herodotos består som ovan nämnt av egna reseminnen och läsning i Historia. Den unge reporterns liv på väg ut i världen tycks, som påpekat, bildligt och bokstavligt talat börja på tröskeln till sin första resa. En biografisk undersökning måste dock ta hänsyn till att Kapuściński en enda gång nämner en episod ur sin barndom, vilket skickligt utnyttjas för att visa en avgörande likhet med en hel kontinent. Det rör sig om bristen på skor vintern året 1942. Barnet Kapuściński övertalas av sin familjs husvärd att sälja tvålar för att tjäna ihop till ett par skor. Försäljningen går dåligt, vintern kommer och det skolösa barnet måste avbryta handeln. Småningom går husvärden med på att skjuta till resterande beloppet och han får ett par skor. Han infogar minnet vid åsynen av miljontals barfota indier och får "en känsla av gemenskap och närhet med dessa människor" (Kapuściński 2006). Han använder sig alltså inte av episoden för att knyta an till sin egen person, utan för att dra paralleller mellan sin skolösa och fattiga uppväxt och den barfota och likaledes fattiga subkontinenten Indien. Hans framställning utgår från en kroppslig erfarenhet, känseln och de kalla fötterna, och går därmed raka vägen från upplevelse till inlevelse - som en typisk Thurénsk förklaring genom konkretion. Här upplevs det något hos De Andra som han känner igen hos sig själv, men så är inte alltid fallet.

\section{Herodotos inversion och Kapuścińskis metainversion}

Herodotos' liksom Kapuścińskis reseskildringar har också det gemensamt att de studerar andra kulturer. Denna explorativa och antropologiska aspekt är något av en bieffekt när de reser för att rapportera om händelser och utvecklingar i fjärran länder. Melberg citerar i sin bok Resa och skriva: en guide till den moderna reselitteraturen den franska filologen François Hartog som har beskrivit Herodotos strategi i termer av "att 'översätta' det som verkade annorlunda, annanheten (l' alterité), till det välkända, det egna. Hans retoriska strategi var att göra de främmande kulturer han skildrar begripliga för sig själv och för sina läsare/åhörare med den gena kulturen som förståelsens norm. (...) Herodotos’ normalstrategi döper emellertid Hartog till inversion: det främmande presenteras helt enkelt som motsatsen till det egna. Eller det som det egna inte är. Eller det egna vänt upp och ned eller bakfram.” (Melberg 2005). Att på det här sättet göra annanheten till det anti-egna och därigenom transparent för läsaren, så att annanheten försvinner och istället blir vrångbilden av det egna, tillhör idag postkolonialismens grundbegrepp. Även om Kapuściński är en modern - för att inte säga modernistisk - författare, finns det drag av en transparent inversion även i hans beskrivningar av andra kulturer. Nedan en ganska hämningslös reflektion där Kapuściński jämför indier och kineser på ett explicit herodotiskt och exotiserande sätt. Bägge folkslag har han lärt känna under sina första resor, eftersom han skickades dit som ung och oerfaren korrespondent. I kapitlen Dömd till Indien och Ordförande Maos hundra 
blommor redogör han för förutsättningarna och sina överväldigande möten med dessa för honom helt främmande kulturer, samt sina ansträngningar att förstå dem (jfr Kapuściński 2006).

En indier är en avspänd person, en kines är spänd och vaksam. En indisk folkhop är oformlig, flytande och långsam, en kinesisk är formerad till led, disciplinerad, den marscherar. Det märks att över kineshopen står ett befäl, en myndighet, medan det över indierhopen svävar en areopag av oräkneliga gudar som ingenting kräver. (...) Också ansiktena ser olika ut.

Indiernas ansikte kan ständigt överraska; i pannan kan det plötsligt finnas en röd prick, på kindernas färgade snirklar, och ett leende kan blotta bruna tänder. Sådana överraskningar erbjuder inte kinesens ansikte. Det är slätt och har oföränderliga drag. Ingenting tycks kunna rubba dess orörliga yta. Det är ett ansikte som säger att det döljer någonting vi inte vet och inte kommer att få veta. (Kapuściński 2006, s. 72)

Här skapas tydliga skillnader för att ställa olika kulturella egenheter mot varandra, varvid båda paradoxalt nog upplevs som lika varandra just i sitt sätt att framstå som främmande. Framställningen utger sig för att vara en värdeneutral observation som vemsomhelst kunde ha gjort. Metoden uppvisar klara likheter med hur annanhet skapas hos Herodotos, Kapuściński är så angelägen att förstå och förklara honom, att hans dialog med Herodotos antar formen av en litterär byteshandel:

Han [Herodotos] lämnar Nilen och gåtan med dess källor, hemligheten med hur flodvattnet stiger och sjunker med årstiderna, och börjar observera egyptierna, deras sätt att vara, deras seder och bruk. Han hävdar att så har de också $i$ nästan allting seder och bruk, som är rakt motsatta andra människors.

Och han registrerar omsorgsfullt:

Hos dem går kvinnorna på torget och handlar, men männen sitter hemma och väver... Bördor bär männen på huvudet men kvinnorna på skuldrorna. Kvinnorna står upprätt, när de kastar sitt vatten, men männen sitter. Sin nödtorft förrättar de inomhus, men de äter ute på gatorna.

(...) Nej, Herodotos förfasar sig aldrig, fördömer inte det främmande, utan försöker lära känna det, förstå och beskriva det. Särarten? Den finns till för att framhäva enheten, skänka den livaktighet och rikedom. (Kapuściński 2006)

När Herodotos’ uppsåt, tankar och intentioner ska förklaras för en samtida läsare kommer en slags metainversion till uttryck, den herodotiska inversionen inverteras en gång till, men nu för att göra Herodotos' strategi begriplig. Även här kan man få syn på den biografisering som jag menar kännetecknar Kapuścińskis metod, att gestalta text med (eget) liv. Transparensen mellan Kapuściński och Herodotos sker underförstått och smygande inom ramen för det alltid närvarande gränsöverskridandet. 


\section{Tillbaka till Herodotos}

Transparensen kommer även till uttryck i intresset för Herodotos' arbetsmetod som Kapuściński liknar vid sin egen som skrivande världsreporter. Den litterära fantasin i skildringen känns igen som ett flitigt använt verktyg vid det här laget:

Hur arbetar Herodotos?

Han är den borne reportern: han reser, tittar, samtalar, lyssnar, för att sedan skriva ner det han sett och fått veta, eller helt enkelt för att lägga det på minnet.

(...) Är han ensam, eller har han en slav med sig? Det vet vi inte, men på den tiden höll man sig med slav om man hade råd med det. (...) Kanske liknade relationen mellan Herodotos - en vetgirig romantiker som var ute efter vetande för vetandets skull, en nitisk utforskare av opraktiska angelägenheter till ringa nytta för någon - och hans slav (...) förhållandet mellan Don Quijote och Sancho Panza, en sorts forngrekisk version av det kastilianska paret längre fram i tiden. (Kapuściński 2006)

Kapuściński spekulerar kring huruvida Herodotos var ensam på sina resor, om det var ett ensamt projekt, ett enmansföretag. Kapuściński utrustar honom gärna med olika typer av kompanjoner, och det är svårt att bortse från hur han i kontrast till det har beskrivit sitt eget uppdrag som i grunden solitärt. Den ovan föreställda slaven är en sådan kompanjon, jämförelsen med Don Quijote och Sancho Panza antyder både en intimitet och en nivå av romantisk galenskap i det omöjliga uppdraget. Kapuścińskis önskan om att vara där gäller, förutom platsen, även tiden för Historia och figuren Herodotos; rentav som hans studieobjekt: ”Om Jarda [tjeckisk kollega] och jag hade levt på Herodotos tid skulle vi ha varit skyter (...). Herodotos skulle ha varit mycket intresserad av oss, frågat om våra sedvänjor och trosföreställningar, om vad vi åt och hur vi klädde oss." (Kapuściński 2006). Kapuścińskis önskan om att få överskrida gränsen når sin fulla potential här: ”Och liksom jag en gång i tiden hett hade önskat att få överskrida gränsen i rummet blev jag nu fascinerad av att överskrida gränsen i tiden.” (Kapuściński 2006). Denna ohämmade beundran för Herodotos som Kapuściński ger uttryck för i kapitlet Herodotos upptäckt visar på en igenkänning i Herodotos’ person och livshistoria som kan förstås med hjälp av begreppen transparens, identifikation, och möjligtvis även som överföring/motöverföring i freudiansk mening. Men än en gång: Kapuściński är varken Herodotos eller sin egen biograf, varför de strikt vetenskapligt biografiska termerna måste användas med försiktighet. Men biografiseringen av Herodotos som representant för Kapuściński går inte att ta miste på.

\section{Källkritik och självkritik}

Med tanke på hur Kapuściński använder Herodotos, hur kritisk är han mot sin källa i sina undersökningar? Enligt Wästberg har information hos Kapuściński som ögon- och öronvittne och i egenskap av reporter en mycket speciell status:

Hans skrivsätt utmärks av subjektiva värderingar av händelser och personer, sammansatta karaktärer, påhittade scener, direkta citat, inre känslor och tankar, återgivande av odokumenterade fakta och en skönlitterär teknik för att åskådliggöra icke fiktiva ämnen. 
Inlevelse och övertygande framställning går före kravet på verifiering. Inga källhänvisningar - han är själv källan (Wästberg 2009).

Den poetiska hyllningen är ganska förlåtande gentemot bristen av källkritik i Kapuścińskis produktion. När Kapuściński i På resa med Herodotos citerar flitigt ur en för en gångs skull namngiven källa, så väljer han ändå en författare som har förblivit anonym som historisk person, samtidigt som innehållet i Herodotos framställningar i sin tur har ett tveksamt källvärde. Enligt Thuréns definition är de mer kvarleva än källa (Thurén 2005), de säger mer om författarens världsbild än om faktiska historiska och geopolitiska förhållanden. Visserligen påvisar Kapuściński i en lång citatlista Herodotos’ förbehåll och reservationer mot sin tids källor (jfr Kapuściński 2006), men dessa ickeverifierbara sekundärkällor smittar av sig på en källkritisk rundgång i Kapuścińskis text.

I Thuréns grundbok i ämnet källkritik med samma titel ${ }^{16}$ behandlas de källkritiska principerna. Jämte kriterierna äkthet, tidssamband, oberoende och tendensfrihet skiljer Thurén mellan berättelser om något (källa) och kvarlevor av något (kvarleva, lämning) (Thurén 2005). Dessutom tillkommer urval av fakta som en viktig pusselbit i tolkningen. Lindqvist och Söderlind åskådliggör problematiken i sin för digitala förhållanden uppdaterade bok Informationskompetens ${ }^{17}$. Genomgående för den kritiska prövningens syfte är att som "källkritisk aktivitet” tilldela källan ett relevant "källvärde" (Lindqvist \& Söderlind 2009). Denna form av systematiskt kontextualiserande gäller för historisk och i viss mån för all vetenskaplig forskning.

Kapuściński arbetar inte enligt någon vetenskaplig diskurs med sin läsning av Herodotos, men är vagt medveten om de källkritiska begränsningarna med Historia. Han kontextualiserar inte gentemot andra relevanta källor, men är å andra sidan inte heller ute efter ett entydigt eller vetenskapligt säkerställt källvärde. Kapuściński kontextualiserar i första hand gentemot sin egen textproduktion, mot egna tidigare läsningar av Herodotos och mot egna mångåriga erfarenheter av att resa och skriva - "han är själv källan" (Wästberg 2009). Problemet är att Kapuściński själv inte gör skillnad på de olika läsarterna när han ger sig på historieskrivningens fader. Beroende, tidsskillnad och partiskhet gentemot auktoriteten Herodotos är snarare en dygd än en last i Kapuścińskis fall. Wästbergs omdöme ovan kan med fördel appliceras även på Herodotos. Källans anonymitet står mot tolkningens auktoritet.

Både Kapuściński och Herodotos kan sägas arbeta innanför diskursen för den s.k. kognitiva auktoritet som lanserades i början av 80-talet av Patrick Wilson, professor vid University of California i Berkeley (Lindqvist \& Söderlind 2009). En källas tillförlitlighet kan kompletteras med, men även kompliceras av en persons trovärdighet. Det är inte källvärdet hos varken Herodotos text eller sina egna redogörelser som styr användbarheten för Kapuściński, det är hur texterna influerar i kraft av sin auktoritet. Med anspelning på rubriken ovan kan man säga att bristen på källkritik och självkritik utgör risken Kapuściński

16 Thurén, Torsten (2005). Källkritk. Stockholm: Liber.

17 Lindqvist, Martin \& Söderlind, Peder (2009). Informationskompetens: en grundbok. Stockholm: Santérus. 
är beredd att ta för att föra fram sin berättelse om människans livsvillkor. Wästberg sammanfattar:

Ordet historia betydde på Herodotos tid undersökning, efterforskning. Kapuściński var även han resenären från en civilisation som söker kontakt med en annan och förmedlar den. (...) Han daterade inte, angav sällan exakta namn på orter eller byar; han nådde en större trovärdighet eller sanning genom att ordna sitt material fiktivt, litterärt. Det är närvaron som gäller (Wästberg 2009, s. 256).

\section{Reporterns självporträtt}

Boken Reporterns självporträtt (Kapuściński 2008) beskrivs som "en samling av Ryszard Kapuścińskis (1932-2007) intervjuer, föreläsningar och samtal. Han berättar om sin kringflackande barndom, om sitt sätt att bedriva reportaget som genre och om den ensamhet och rädsla som är den kringresande reporterns följeslagare.” ${ }^{18}$ Dess speciella form av citat ur en samling befintliga texter är på många sätt olik Kapuścińskis normala textproduktion. Dels handlar det ofta om personen Kapuściński själv, dels bildar de en ickekronologisk och kalejdoskopisk stafett av korta och synbart fragmenterade utdrag ordnade efter ett antal temarubriker. ${ }^{19}$ Eller som förordet av Krystyna Straczek beskriver det: "Och av obetydligt modifierade fragment ur ett fyrtiotal intervjuer, föreläsningar och samtal blev det en bok i fem scener: Reporterns självporträtt. Boken har godkänts av författaren och överlämnas nu till Läsaren” (Kapuściński 2008). Kapuściński har alltså i strikt mening varken skrivit eller redigerat texten, utan endast uttalat sig i olika sinsemellan vitt skiftande sammanhang, varför självporträtt känns en aning förmätet som genrebeteckning. Det förblir okänt om detta självporträtt tillkom i väntan på en reguljär självbiografi, för att förekomma andra typer av porträtt eller rentav som ett offensivt och nytt grepp av Kapuściński där han låter andra lägga det egna arbetslivets pussel, till form och längd inte olikt korta tidningsnotiser.

Den litteraturvetenskapliga distinktionen mellan porträtt och biografi utgår vanligen från att "uppfatta porträttet som verk- och textorienterad medan den biografiska litteraturforskningen är personorienterad" (Olsson 1997). ${ }^{20}$ Traditionellt går distinktionen här även mellan icke-vetenskap (porträtt) och vetenskap (biografi), men Olsson skiljer åt begreppen med hjälp av termerna genre och metod: "I termer av metod är skillnaden mellan biografi och porträtt att den förra strävar efter att förklara text med hjälp av liv, medan den senare söker konstruera liv utifrån text." (Olsson 1997) Tillämpad på beteckningen självporträtt i Kapuścińskis fall kan boken knappast sägas höra hemma i genren porträtt. Däremot kan boken, eller snarare textsamlingen, betraktas utifrån porträttet som metod enligt Olssons omkastning, att "konstruera liv utifrån text.” Den stafettliknande textformen har essäistiska drag i hur den spårar upp tematiska trådar på tvärs mot det kronologiska i Kapuścińskis produktion; uppsåtet framstår i hög grad som konstnärligt snarare än vetenskapligt.

$18 \mathrm{http}: / /$ www.syndetics.com/index.php?isbn=9100122874/swedsummary.html\&client=sodertns\&type=rn12

19 I (Hur resandet började), II (Hur journalistiken började), III (Skrivandet), IV (Efter succén) och $\mathrm{V}$ (Medier)

20 Ambjörnsson, Ronny \& Ringby, Per \& Åkerman, Sune (red.) (1997). Att skriva människan. Essäer om biografin som livshistoria och vetenskaplig genre. Stockholm: Carlssons. 
Reporterns självporträtt är lättare att beskriva utifrån en negativ definition: Den präglas av ickekontinuitet och saknar biografisk konsekvens. Livet framstår inte som helhet eller enhet, utan snarare som en fragmenterad tillvaro med Kapuściński ständigt på språng, och ett notisblock fullklottrad med anteckningar och sentenser innanför västen, ibland lika tvärsäkra som motsägelsefulla. Biografin som antingen bekräftande eller opponerande och därmed en tolkning av liv uteblir (jfr Olsson 1997). I vag postmodernistisk anda har författarens röst splittrats och sammanfogats till en polyfonisk flerhet, livstidens kontinuitet och världens rumslighet har krympt till ett antal punkter, kvar är en författarröst som talar från många platser och positioner samtidigt. Resultat är en citatsamling gjord som för att citera ur. Ett enda citat nedan får representera en i längden svårläst citatsamling

(...) Mina dikter var mest av tillfällighetsnatur, och ändå var det de som förde in mig i journalistiken, redan under skoltiden. När man bildade redaktionen för "ungdomens standar" fick jag förslaget att arbeta där. Jag sade att jag måste ta studenten först, så de väntade på mig. Bokstavligen dagen efter att jag klarat alla mina tentamina började jag arbeta på redaktionen. Att jag blev journalist har jag poesin att tacka för, och inte poesi av bästa sort, fast min egen. Men min dröm var att bli målvakt i Polens landslag. [1993] (Kapuściński, 2008).

Citatet kan sägas vara exemplariskt för flera saker samtidigt: Dels beskriver Kapuściński sin yrkesbana som mer eller mindre kantad av tillfälligheter, som ett hopp eller ett gränsöverskridande från poesins håll, dels framkommer hans flit och iver i det att han började arbeta som journalist "dagen efter" sin utbildning. Som prov på den poetiska journalist Kapuściński vill vara avslutar han denna korthuggna självframställning med att han egentligen ville bli fotbollsproffs. Till synes taget ur luften, om än troligen sanningsenlig, kastar han in bollen från sidan: personen Kapuściński är egentligen någon annan, tycks han säga, på väg till en match, av nödvändighet och omständighet driven till att skriva journalistik i poesins tecken. Och han gör det snabbfotad och med sportslig elegans.

\section{Slutord istället för slutsats}

Jag vill påstå att motiv och medel ofta går ihop: Kapuściński använder sig själv ofta som en tämligen "passiv" betraktare, hans position är vittnet, och själva positioneringen möjliggör för läsaren att se världen, att bevittna den med Kapuściński, att resa och läsa med honom. Som läsare lånar man Kapuścińskis blick på ett ibland påtagligt visuellt sätt. Här lånar dessutom Kapuściński Herodotos' blick, positionen av betraktare och vittnet går igen i Herodotos undersökningar, vilket får effekten av en metainversion. Kapuściński som läsare, vittne och ivrig citatör av Herodotos text, skriver in sig som Historias medförfattare och uttolkare, han bidrar rentav till en postmodernistiskt färgad och förlängd utvidgning av Historia. Det som förbinder båda reseberättelser är just uppsåtet och ambitionen att skriva, kanske inte människans, utan snarare människors historia. Kapuściński och Herodotos som sinsemellan transparenta subjekt ger skildringen dess liksom flytande komplexitet.

Bokens flerskiktade undersökningar och tidsepoker(Herodotos Historia och Kapuścińskis minnesresor) varvas om vartannat och bidrar till dess både fragmentariska, repetitiva och 
cykliska karaktär, där vissa motiv återkommer i intervaller. Det har en dubbel effekt: Det entydigt säkra och objektivt sanna när det gäller fakta bryts mot en subjektiv och fiktivt förhöjd sanning baserad på egna upplevelser. Projektet På resa med Herodotos drivs även av en viss romantisering eller nostalgisering av det historiskt förflutna i sättet att återfinna en plats bland de "grand narratives”, i en återblickandets försoning med en tid när samhällets strukturer var enklare att överblicka och berätta om: kungar, krig och konflikter.

Kapuściński har blivit synonym med ett humanistiskt färgat reportage som vågar stå upp för journalistiska dygder som närvaro, närhet och respektfull inlevelse och samtidigt försöker förnya eller rentav uppfinna sin egen form i en mer essäistisk anda. Att såväl uppsåt som metoder skulle komma att synas i sömmarna genom ett kritiskt biografiskt arbete som Domoslavskis Kapuściński Non-Fiction var att vänta. Kanske speglar det en annan dygd som har att göra med källkritisk transparens och trovärdighet. Det är inte säkert att Domoslavskis arbete gör kravet rättvisa, mycket står på spel i denna uppgörelse som har beskrivits som ett fadersmord i pressen. Kapuściński har sin produktion igenom tänjt på gränsen mellan det säkra och sannolika, i syfte att kunna förstå och skildra människan belägenhet. Det är framför allt genom sin position och sin blick han har uppnått auktoritet, genom att kunna fördjupa och litterärt gestalta sådant som vanligt bara flimrar förbi som nyheter. Även om delar av den bild han tecknar visar sig vara falska eller konstnärligt förvrängda talar den ändå i kraft av sin gestaltning, här finns gott om tidlösa iakttagelser som är skarpsynta och utrustade med en okuvlig tro på människan, en vilja att förstå henne genom inlevelse. 